\title{
The adoption of technology in Higher/ Nursing Education
}

\section{S M Meyer, MEd (CAE), Department of Nursing Science, University of Pretoria}

\section{Abstract}

This is a review article on the adoption of technology in higher education. Higher education in general is looked at. Nursing Education is also higher education and therefore it will not be addressed separately, but mentioned in some instances. The article presents a look into how students and lecturers experience change, as well as barriers they perceive in the integration and adoption of technology. Some suggestions are made to the adoption process as well as the necessity for personnel development in information technology. The role that Information Technology personnel play in the adoption and integration process of technology is also discussed.

\section{Abstrak}

Hierdie is ' $n$ oorsigartikel wat die integrasie van tegnologie in hoër onderwys aanraak. Hoër onderwys in die algemeen word bespreek. Verpleegonderwys is egter deel van hoër onderwys en sal daarom nie spesifiek aangespreek word nie, maar genoem word in sekere opsigte. Hierdie artikel bied ' $n$ kykie in die wyse waarop studente en lektore/ dosente veranderinge ervaar, asook die struikelblokke wat hulle ervaar in die integrasie en implementasie van tegnologie. Voorstelle ten opsigte van die implementeringsproses word gemaak asook die ontwikkeling van personeel in inligtingstegnolgie. Die rol wat inligtingstegnologie personeel in die integrasieproses van tegnologie speel word ook aangeraak.

\section{Introduction}

Institutions of higher learning are experiencing exciting yet distressing times. New learning and teaching needs will and are emerging, some existing learning and teaching needs will evaporate, and others will continue to exist. As institutions recognise the signals of change, they will most likely take the necessary steps to seize the opportunities of the future (Dean 1989: 278). The pace of arrival of attractive new options for the facilitation of learning is fast. Demographics are not really a problem anymore, as the competition for students have broadened to an international one.

\section{Historical overview of technology}

It was thought film would replace books in the 1930's. As we all know, it never did. Films could be compared to the Internet. Filmmakers make use of all kinds of tricks and trade secrets to make things look real. This can be deceiving for people who find it difficult to distinguish between reality and make-belief situations. It might also be difficult for people to distinguish between right and wrong if they do not have prior knowledge of what is happening on screen. Using the Internet is risky due to the fact that not all information is peer reviewed or accredited by academic institutions. The Internet is a web of information, graphics, animations and even video material that may be useful or informative, but it may also be harmful and incorrect. All of this people can access via their computers provided they have the necessary software and a service provider. Textbooks and journals therefore will not likely be replaced.
Three decades ago, it was the audio-visual mode that ruled our world. Lecturers were filled first with the wonder of films, and later on video programs. The waters of multi imagery were tested. First it was one or two screens, then three, and then dozens (Cornell 1999:60). A lecturer is now faced with newly developed technology or is it rather technology that existed already but is only now being suggested as a solution to educate the masses. The reason for lecturers experiencing these challenges and changes might be due to the fact that the world has become a global village. Adding to this the fact that most everything in life has become automated. Technology as such has crept into our lives without us being aware of it. Now it seems that educators have become aware that they are not facilitating learning for the future, but for the present. It might also be that the information technologists have identified the education market as one of profit making.

\section{Current influences of technology}

As technology develops and information becomes more available to the community, health care demands change. Technology has democratised information and in the process shifted the points of access and control from the professional to the educated public. This influences the manner in which health care providers are educated. The changed relationship to information result in reform. Reform happens by means of a process. This process includes lecturers, students and health care consumers. With this shift then, the focus of education shifts from content to critical thinking skills, collaboration and shared decision-making (Nugent \& Lambert 1994:227). 


\section{Educators and change}

As colleges and universities focus their attention on the implications of forces at work, they will begin to equip themselves with management tools and techniques needed to effect change and will thus become "change agents" (Dean 1989:278). Many lecturers still resist and refuse to use technology. Some resistance is due to high cost, but some is from lecturers who fear they will be replaced by a machine (Dean 1989:280).

Lecturers already know that they have to be life-long learners. They do know that it is required of them to be generalists, and that they have to learn about learning. If they want to employ modern technology to facilitate learning, they have to be dedicated to implement technology.

\section{Incorporating technology into higher education}

Institutions of nursing education are faced with health care reform and knowledge explosion. Therefore, nurse educators are not only being asked to overcome obstacles associated with higher education but to educate practitioners for the new millennium (Nugent \& Lambert 1994:226). Making them afraid that they will not be able to handle education of the future if they do not become technologically literate will not encourage lecturers and students. Fear is a poor motivator for change. Fear should be replaced with trust.

\section{The slow adoption of technology into higher education}

Efforts to adapt or change usually result in increasing pressure on academia and drastically affect the demands made on them. These demands are often vague, obscure, conflicting, incomprehensible and characterised by limited guidance, unrealistic deadlines, too much information and irrelevant information. Lecturers are also faced with conflicting value systems, vague role expectations and a lack of accountability and permanence. They react to these increasing demands and pressures in one of two ways: they either accept the situation as a challenge, or they perceive it as a threat. If lecturers perceive technology as a threat it may be linked to resistance to change (van Dyk 1992:575).

\section{Why are computers so little used for teaching?}

The reasons for this are many: some no doubt reflect the quality and nature of available material, and others concern the educational context in which technology is to be used. Other reasons may concern the organisational and political context. Institutions and departments, whether by intent or default may give little assistance to those wishing to exploit innovative approaches. Indeed, some argue that the key factors required to develop educational computing in tertiary institutions are organisational and advocate a strategic approach through centralised but co-operative management (Hammond, Gardner, Heath, Kibby, Mayes, McAleese, Mullings, \& Trapp 1992:155).

The predominant finding from surveys done in the UK is that lecturers perceive lack of time (whether for modifying courses, evaluating courseware or developing materials themselves) as a major barrier. Also high on the list of priorities are the lack of support staff, the lack of training and a lack of information on suitable materials. It is interesting that factors such as the lack of student access to hardware and quality of software are not considered to be such strong blocks to computer use. These findings are in accordance with the view that significant improvements could be brought about by changes in organisational policy. For lecturers to find time implies in part a change in institutional priorities through policies, support structures and rewards, and in part a reduction in the size of perceived barriers. Perceived barriers to the adoption of Computer Assisted Learning (CAL) can be lowered through better information, staff training and the provision of appropriate development tools (Hammond et al 1992:157).

It appears that it is only through increased familiarity leading to increased use that both benefits and problems are recognised. It seems to be an evolving situation, where once resources made available they are used firstly to enhance staff interests and then filter down to use with students (Hammond et al 1992:158).

Thus the very idea of the computer as a cognitive tool, as an augmenter of individual intelligent human performance, was the concept that required a long gestation period. It may be that this represents the necessary process, and the same slowly dawning realisation about CAL as seen by the mainstream world of education. Perhaps the main stumbling blocks to the implementation of CAL on worthwhile scale lies in the fact that the idea has not yet been put across properly. On the other hand, the wrong idea may have been sold. To expect the educational system to go from a world almost totally without technology, except where teaching people how to use the technology is the point of exercise, to a world where most learning occurs from a computer screen, is too big a jump.

Tertiary educators do not necessarily receive formal training to teach, and this might be seen as a barrier. The reason being that they are not recognised as educators by their peers and they lack the knowledge and experience of education theory (Hammond et al 1992:161-162).

It is perceived that most students lack access to hardware and software. This should not be a problem for students residing close to tertiary institutions that make provision for students in this regard. The students in question are those who would register for a distance education course of a program that 
would probably be presented by means of specifically telematics and/or virtual reality. Virtual reality implies that both student and lecturer interact in cyberspace (encompasses all functionalities and divisions of an institution and concomitantly provides more products and services to students through the attributes of specific technologies). This means through the Internet and the Web regarding all issues such as doing assignments, finding subject content and requirements, and students can even chat to each other in specifically allocated chatrooms on the Internet. Not all courses are however suitable to be driven by using the Internet or WebCT, which is a software program that can be used for online education.

New technology is creating new educational challenges and opportunities, but it also creates new problems. Currently, one of the more serious problems, and the primary impediment to the integration of technology into higher education, is the lack of an efficient support system for lecturers using instructional technology. In some cases, this deficiency is due simply to a lack of funds needed to hire additional Information Technology (IT) personnel (Maddux, Cummings \& TorresRivera, 1999:43).

\section{Lecturers and IT personnel}

Many IT centres need additional personnel and funds to support them. However, additional resources and positions alone will not solve the problem. According to Maddux et al (1999:44) a large part of existing problems are attitudinal. The attitudes concerned are that of both lecturers and IT personnel, both of who often demonstrate:
•

$\bullet$ a lack of understanding of each other's mission, prob -lems, and limitations

a tendency for each to blame the other for prob -lems that occur

little or no inclination to communicate constructively in a problem-solving spirit

Lecturers often regard IT personnel as indifferent to instructional needs and problems and interested only in technical issues, unable to communicate in jargon-free language with non computing professionals, and arrogant concerning their own technical knowledge and expertise. IT personnel, on the other hand, often regard lecturers as impatient and unrealistic in their expectations, lacking in basic computer literacy, unable to describe specific computing needs and problems accurately, and arrogant concerning their advanced degrees and institutional titles. Both views are stereotypical and contribute to a counter-productive, adversarial relationship. Added to this, some lecturers conclude that technology is simply too unreliable and creates too much stress to incorporate in their courses (Maddux et al 1999:44).

\section{Student evaluations}

Lecturers know that students base their evaluation of courses heavily on their perceptions of the "entertainment value" of a course and that they are not entertained by technology fail- ures. For these reasons, and also because most educators take pride in their teaching evaluations and honestly strive to be good teachers, disasters such as those described, often cause frustration and panic on the part of the lecturer. IT personnel should realise that computing failures can and do have serious consequences in the professional appearance of instructors, and that an instructional computing failure can be far more than a minor inconvenience (Maddux et al 1999:45).

There will always be problems that cannot be solved on the spot, and therefore lecturers should always have a back-up plan in the case of technology being unavailable. Transparencies of the critical Websites, or videotapes are but some examples. It is extremely difficult for IT personnel to help lecturers who find it difficult or impossible to describe their computing problem properly. Furthermore, if lecturers do not understand basic computer terminology they will have a great deal of difficulty following any solution suggested to them. Lecturers should therefore make an ongoing effort to improve their computer literacy skills (Maddux et al 1999:46).

\section{Suggestions to assist the adoption and integration of technology}

An important condition for the successful introduction of technological change in organisations is that the individual must be consulted. The development of lecturing staff is very important. To encourage the growth of computer use that will enhance teaching and learning, a good place to start would be with a better overall IT strategy. Issues that would need particular addressing would be issues political and organisational in nature. Improving funding, especially for undergraduate facilities, enabling staff to acquire the necessary skills and experience must receive attention (Hammond et al 1992:158).

Lecturers need a careful awareness process of how to utilise multimedia (a broad term describing multiple media types being accessed interactively via computers). Lecturers have to learn about multimedia first before they can explain to students why and how to use it. They must be able to change methods on a frequent basis to prevent students from becoming bored. By employing constructivist methods will allow students to develop their own ideas. Web-based learning is not automatically motivating. The novelty doesn't last long; it must be bolstered by selected content and powerful strategies (Watson \& Rossett 1999:31).

Kommers (1999) is of the opinion that an experienced lecturer or subject specialist is not necessarily the best person to put in charge of a project. Success to this type of approach will be linked to the lecturer's experience and attitude. They must enjoy what they are doing. Keats (1998) is of the opinion that the lecturer should have ample support to make a technologically based course work. He suggest the following support:

- graphical artist, 
web developer,

- use post-graduate students to mark assignments,

- dedicated technical assistants

- $\quad$ external funds if available

Gilbert (1998) and Kommers (1999) are of the opinion that creativity should be encouraged. Cronjé (1999) emphasises that if you want creativity you must award creativity. The head of a department must be involved with change and incorporation of new technology. Student technical assistance programs should be developed. Unfortunately no tertiary institution has enough academic personnel to assist students.

\section{Personnel Development as Part of the Solution}

The key to personnel development is empowerment. It is necessary to empower lecturers to take responsibility for governance. Robbins (1986) in Nugent \& Lambert (1994:226) suggests seven basic characteristics necessary to develop and cultivate power:

\begin{tabular}{|l|l|}
\hline 1.passion & 2.energy \\
\hline 3.beliefs & 4.bonding \\
\hline 5.strategy & $\begin{array}{c}\text { 6.mastering communica } \\
\text {-tion }\end{array}$ \\
\hline 7.clarity of values & \\
\hline
\end{tabular}

It is possible for a department to facilitate and nurture these characteristics in lecturers by developing leaders within the organisation and by providing an environment that promotes intrapreneurship. Manion (1990) has defined an intrapreneur as an entrepreneur who initiates innovation within the organisation (Nugent \& Lambert 1994:226). Intrapreneurship involves nurturing entrepreneurial energies to help establish creative new activities within the existing organisational framework. During this time of challenge, it is important to harness the energy and creativity of lecturers toward the goals of the organisation.

The first principle in creating an environment for intrapreneurship recognises that intrepreneurial lecturers are usually self-selected or self-appointed. This person might be viewed as being aggressive and complaining and quite often ignored. Therefore it is important to recognise and support the efforts of intrepreneurial lecturers (Hollander et al 1992:227). Principles for intrapreneurship address the concept that lecturers should have the autonomy and authority needed to follow projects through from the original idea to the completion thereof. Frustration results when lecturers are given a project to develop without information or authority to com- plete the project. It is helpful to create opportunities for lecturers to network with individuals who can serve as mentors (Hollander et al 1992:228)

Manion (1990) in Hollander et al (1992:229) is of the opinion that maintenance of an intrepreneurial environment promotes empowerment of lecturers, resulting in critical thinking and problem solving. The lecturer who remains within an organisation as an intrapreneur has the advantages of continued personal development, increased personal satisfaction, and rewards and recognition that come from successful innovation within the workplace

\section{Finances}

Changing the educational program and instructional process is one of the most sensitive and difficult ways to attempt to achieve economy. Yet financial crises will force an institution not only to examine its central tasks of selecting and instructing students but also to apply modern technology to teaching (Dean 1989:278-279). After performing a study of financial variables, such as the accounting of records, purchasing of records, maintenance and supply of records from many higher educational institutions in the United States, Dean (1989:278-279) came to the conclusion that teaching becomes more expensive when computing technology is used in the teaching process. No lecturer could be substituted by technology. Achieving cost-effective application of computer technology is unlikely, since whatever the technology costs are will be added to the already existing expense of the traditional approach.

\section{Conclusion}

Distance education and thus the use of technology for educational purposes are here to stay. Before adopting technology for delivering an educational program, the program should be assessed as to whether or not the content and nature thereof justifies the use of IT. Never should one individual lecturer be responsible for a distance educational program presented by means of IT.

IT experts and subject specialists should also be involved and serve as support structures. Lecturers should be properly trained in the use of technology and how to manage unexpcted problems. Not only should lecturers become IT literate, so should managers and students of faculties of HE institutions. The insterest and support should realise in a vertical as well as horisontal manner for programs to be successful. Before implementation of technology in education, a proper strudy should be done regarding the learning needs and technological capacity of the possible student population. Marketing should then be done to inform that community that the specific program exists. Only then should such a program be launched, as only then it will become financially feasible. 


\section{References}

CORNELL, R 1999: The Onrush of Technology in Education: The Professor's New Dilemma. Educational Technology. May-June, 1999. 60-64.

CRONJÉ, JC 1999: Professor in the Faculty of Education, University of Pretoria. Education Forum. University of Pretoria.

DEAN, RL 1989: A Model for Evaluation of Cost-Effectiveness of Computer-Assisted Instruction in a University. Journal of Research on Computing in Education. 21: (3), 277-289.

GILBERT, S (USA): Multi media for the New Millennium. [A conference of the Educational Media Institute of SAARDHE (SA Association for Research and Development in Higher Education) at the University of Pretoria - SA 3-5 Sept 1998].

HAMMOND, N; GARDNER, N; HEATH, S; KIBBY, M; MAYES, T; MCALEESE, MULLINGS, C \& TRAPP, A 1992: Blocks to the Effective Use of Information Technology in Higher Education. Computers Education. 1992. 18, (1-3): 155162.

KEATS, D. 1998: Multi media for the New Millennium. [A conference of the Educational Media Institute of SAARDHE (SA Association for Research and Development in Higher Education) at the University of Pretoria-SA 3-5 Sept 1998].

KOMMERS, P 1999: Professor at the University of Twente in the Netherlands. Education Forum. University of Pretoria.

MADDUX, CD; CUMMINGS, R \& TORRES-RIVERA, E 1999: Facilitating the Integration of Information Technology into Higher-Education Instruction. Educational Technology. May-June 1999: 43-47.

NUGENT, KE \& LAMBERT, VA 1994: Empowering Faculty Through Intrapreneurship: A Change Model. Journal of Nursing Education, May 1994, 33: (5), 226-229.

VAN DYK, PS; NEL, PS \& LOEDOLFF, P VAN Z 1992: The Development Phase of Training and Design. Training Management. Halfway House: Southern Publishers.

WATSON, JB \& ROSSETT, A 1999: Guiding the Independent Learner in Web-Based Training. Education Technology. May-June 1999: 27-36. 